\title{
Volcanic Hazards at Mount Shasta, California
}

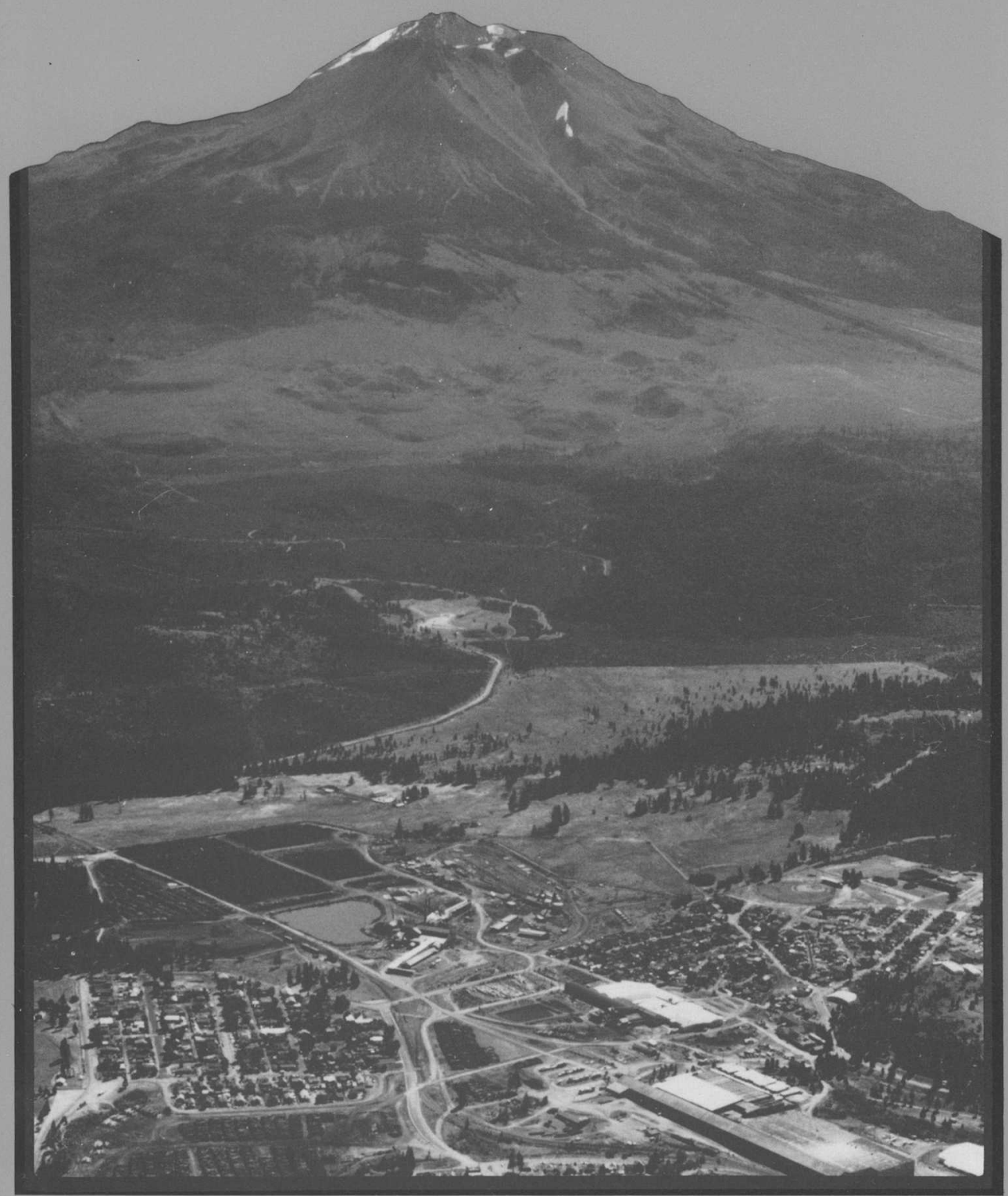




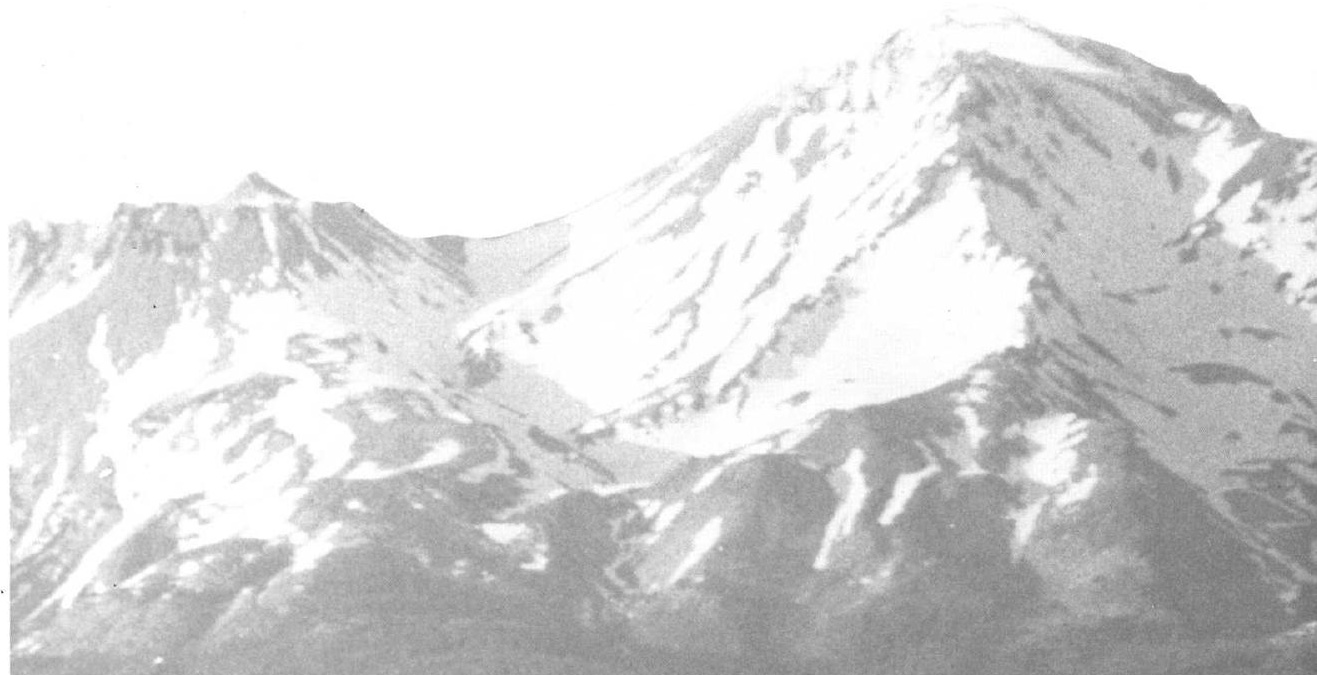

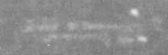

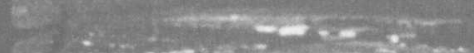

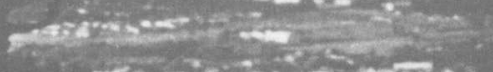

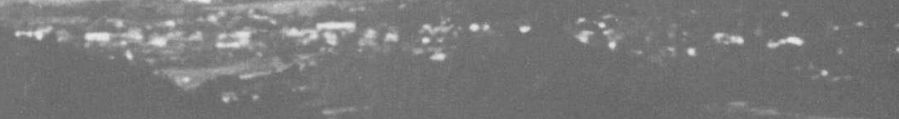




\title{
Volcanic Hazards at \\ Mount Shasta, California
}

\author{
by \\ Dwight R. Crandell \\ and \\ Donald R. Nichols
}

Cover: Aerial view eastward toward Mount Shasta and the community of Weed, California, located on deposits of pyroclastic flows formed about 9,500 years ago. 
The eruptions of Mount St. Helens, Washington, in 1980 served as a reminder that long-dormant volcanoes can come to life again. Those eruptions, and their effects on people and property, also showed the value of having information about volcanic hazards well in advance of possible volcanic activity. This pamphlet about Mount Shasta provides such information for the public, even though the next eruption may still be far in the future.

Locating areas of possible hazard and evaluating them is one of the roles of the U.S. Geological Survey (USGS). If scientists recognize signs of an impending eruption, responsible public officials will be notified and they may advise you of the need to evacuate certain areas or to take other actions to protect yourself. Your cooperation will help reduce the danger to yourself and others.

This pamphlet concerning volcanic hazards at Mount Shasta was prepared by the USGS with the cooperation of the Division of Mines and Geology and the Office of Emergency Services of the State of California. 
An eruption of Mount Shasta could endanger your life and the lives of your family and friends. To help you understand and plan for such a danger, this pamphlet

- describes the kinds of volcanic activity that have occurred in the past,

-shows areas that could be affected in the future, and

-suggests ways of reducing the risk to life or health if the volcano does erupt.

A resident of the Mount Shasta area could ask, "What is the chance of an eruption within the next 10 years or within my lifetime?" This question can only be answered indirectly. The last eruption of the volcano probably was in 1786. Such geologically recent activity suggests that molten rock is still present beneath the volcano. Even though the volcano has not been active for two centuries, Mount Shasta, like Mount St. Helens before 1980, is only dormant and almost certainly will erupt again.

Studies by geologists show that Mount Shasta has erupted 10 or 11 times during the last 3,400 years and at least 3 times in the last 750 years. Mount Shasta does not erupt at regular intervals, but its history suggests that it erupts at an average rate of roughly once per 250 to 300 years. If the behavior of the volcano has not changed, the chance is 1 in 25 to 30 that it will erupt in any one decade and 1 in 3 or 4 that it will erupt within a person's lifetime.

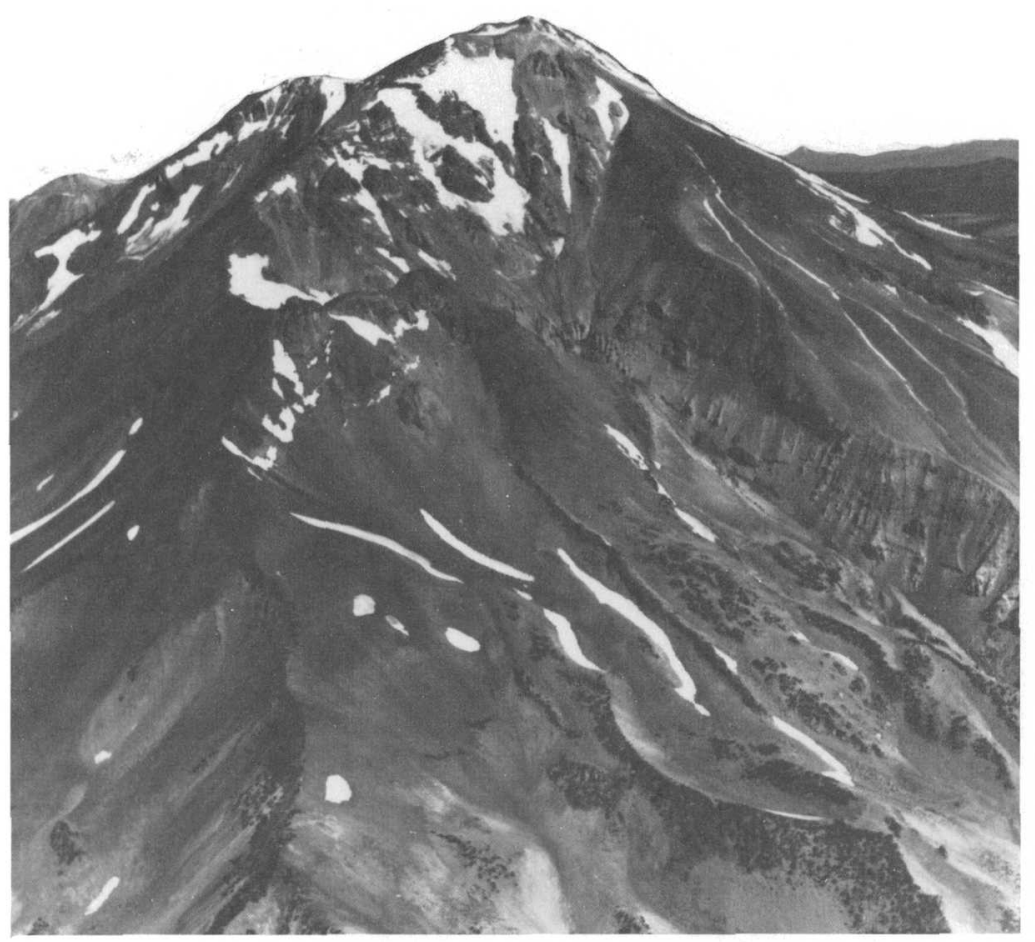




\section{Effects of Eruptions Expected at Mount Shasta}

Both explosive and nonexplosive eruptions have occurred at Mount Shasta and are possible in the future. Explosive eruptions can produce volcanic ash, pyroclastic flows (streams of hot ash and rock fragments mixed with hot gases), and lateral blasts, such as occurred at Mount St. Helens in 1980. Nonexplosive eruptions form lava flows and domes. Both types of eruptions can cause mudflows down local drainages, and both types often are accompanied by gas emissions. All these products of eruptions can endanger people and property, but in different ways; each product is described to explain the possible effects of eruptions and means of protecting yourself if an eruption should occur.

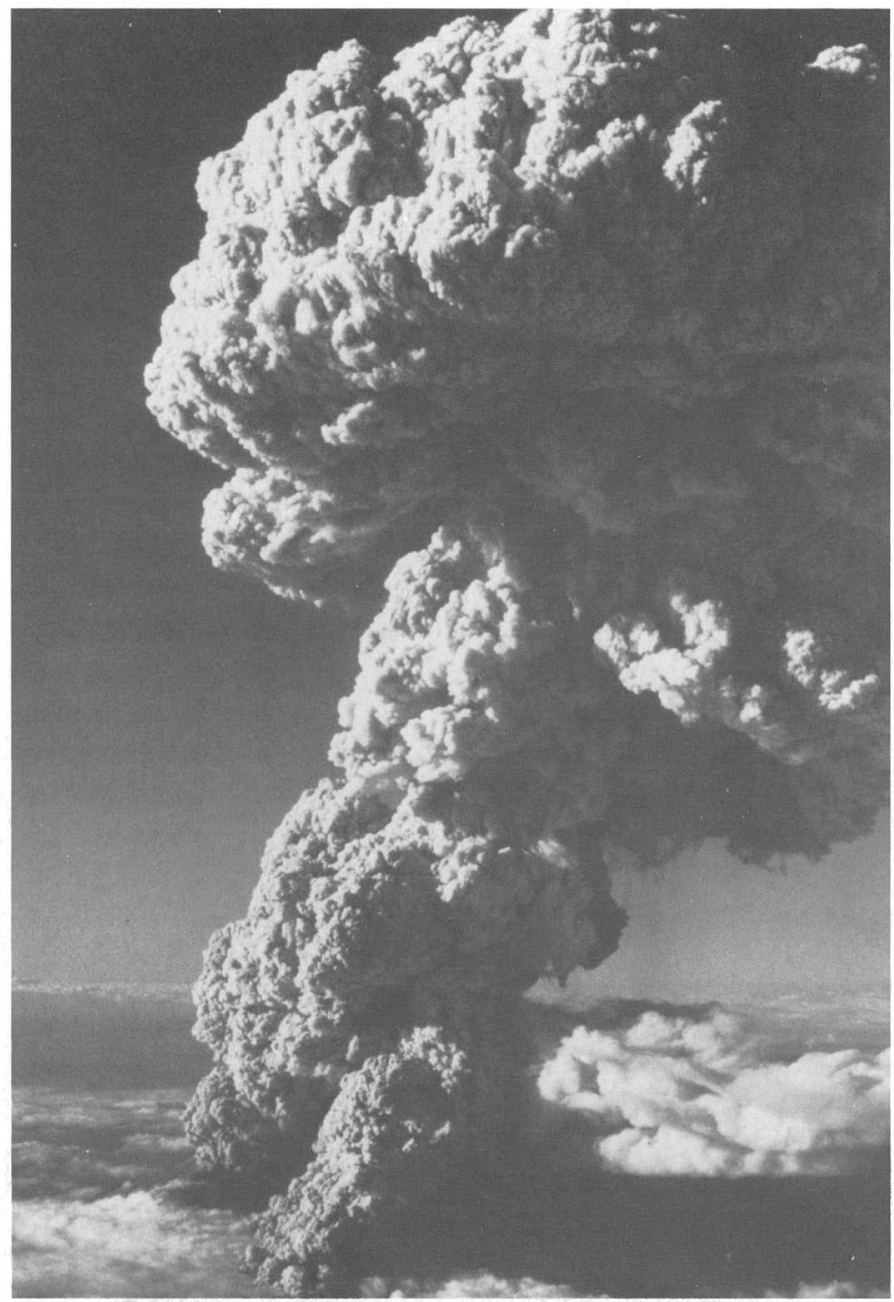

Ash erupted above Mount St. Helens on July 22, 1980, reached an altitude of nearly 9 miles 


\section{Volcanic ash}

Volcanic ash usually is erupted into the air above a volcano and then is carried downwind along with volcanic gases. As used here, the term "ash" includes particles from the size of fine dust to fist-sized or even larger pieces of rock or pumice (a porous form of volcanic rock). Most ash erupted above a volcano is carried away by winds at altitudes up to about 50,000 feet. When the ash falls to the ground, it forms a layer that generally becomes thinner as distance from the volcano increases. The ash in such a layer also becomes finer as distance increases.

Ash can affect health, especially that of persons with respiratory problems, but it usually does not threaten human life. Fine ash falling on water supplies will cause brief muddiness and chemical contamination. Ash also causes rapid wear of machinery, clogs air filters, blocks drains and water intakes, and can injure or kill vegetation. Clouds of ash often cause electrical storms that can start fires and disrupt radio and telephone communication, and damp ash can short-circuit electrical systems. A thick layer of ash can overload roofs, especially if wet, and even small amounts can cause costly clean-up problems. Larger rock fragments that fall close to the volcano can injure people by impact and can start fires if the fragments are hot. Acids that may be present as films on ash particles, or that may accompany the ash as aerosol mists, can corrode metals and decompose fabrics.

Effects of ash on human respiratory systems can be reduced if people stay indoors and breathe through filter masks or moistened cloths. A cloud of ash often causes near or total darkness, and it generally is not advisable to drive vehicles while ash is falling because of the danger of becoming stranded by an ash-caused engine failure or of having an accident because of poor visibility. A closed vehicle, however, would provide some protection during an ash fall.

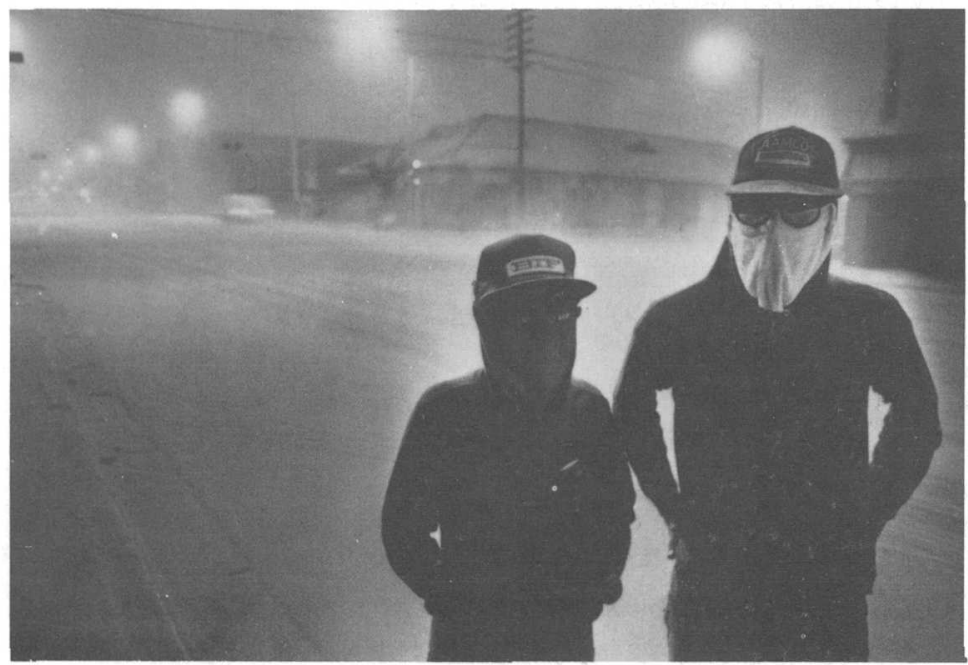

(Photograph courtesy of Yakima Herald-Tribune, Yakima, Wash.) 


\section{Volcanic gases}

Volcanic gases can be emitted by a volcano either alone or along with ash or lava and usually are carried away by winds. Volcanic gases consist chiefly of water vapor, carbon dioxide, carbon monoxide, and various compounds of sulfur, chlorine, and other elements. Winds dilute airborne gases so that they are seldom present in toxic amounts more than a few miles downwind from their source.

Volcanic gases can endanger life and health and some can corrode metals, damage fabrics, and destroy crops and other vegetation. Gases can harm people mainly by injuring the eyes, skin, and respiratory system. Some protection is provided by clothing and goggles and by breathing through masks or moistened cloths.

\section{Pyroclastic flows}

Pyroclastic flows are streams of hot ash and rock fragments, mixed with hot air and other gases, that move rapidly along the ground surface. The gases reduce friction and enable pyroclastic flows to move downslope like liquids for many miles even though the flows do not contain water.

Pyroclastic flows are accompanied by clouds of ash that billow hundreds or thousands of feet into the air above and beyond the flow itself. In fact, a pyroclastic flow sometimes can be recognized from a distance by the ash clouds that rise above the flow as it moves down the side of the volcano.

Pyroclastic flows can form when masses of ash and rock fragments are erupted into the air above a vent and then fall back onto the flanks of the volcano and flow downhill. Such flows also can form when gas-rich lava froths in the throat of the volcano and pours out of the crater as a mixture of hot ash and gas or when a large mass of rock avalanches from the side of a growing volcanic dome (explained below) and rolls downslope as a hot mixture of rock fragments and air.

As pyroclastic flows move down the sides of volcanoes, they often are channeled into the bottoms of valleys. However, broad, smooth areas like the lower slopes of Mount Shasta allow pyroclastic flows to spread widely as they move toward and beyond the base of the volcano.

One type of pyroclastic flow consists of cloudlike masses of hot ash and gases moving so fast that they can sweep across hills and ridges as well as down valley floors. These masses of mostly sand-sized material are called ash hurricanes, and they can form in much the same way as other pyroclastic flows.

Pyroclastic flows and ash hurricanes are especially dangerous because of their high temperature, which generally exceeds that of boiling water, and their high speed, which may be more than 100 miles per hour (mph). Hot rock fragments in pyroclastic flows can set fire to vegetation and wooden structures. Accompanying ash clouds can burn and suffocate people.

Pyroclastic flows and ash hurricanes usually move so fast that escape from them is nearly impossible. They are best avoided by evacuation of threatened areas before an eruption. 


\section{Lateral blasts}

A lateral blast is a sideways-directed volcanic explosion that carries large pieces of rock and ash at very high speed along and above the ground surface. The rock debris carried by the lateral blast at Mount St. Helens in 1980 had an initial speed of more than $250 \mathrm{mph}$, and it was still moving about 60 $\mathrm{mph}$ near its outer limit about 15 miles from the volcano.

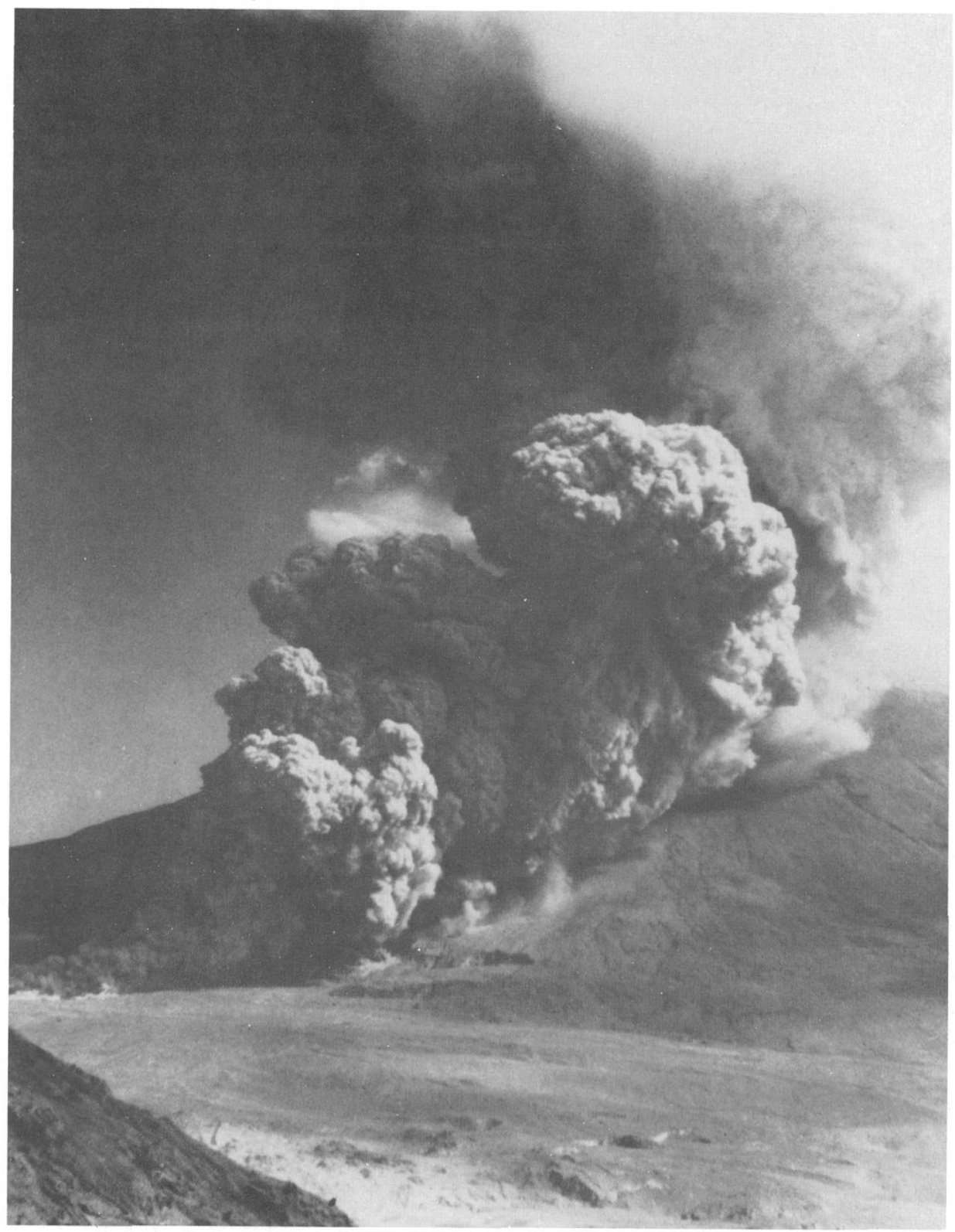

Ash clouds rising above a pyroclastic flow moving down the side of Mount St. Helens on August 7, 1980. 
- Lateral blasts are very dangerous because they can affect areas of many tens of square miles almost instantly, and can kill by impact, burial, or heat. People who survive these effects may be killed by breathing hot air and ash. A lateral blast can knock down a mature forest, as at Mount St. Helens in 1980 , and can demolish most if not all manmade objects in its path.

Scientists might anticipate a lateral blast at an active volcano, but the exact time and size of a blast are unpredictable. Evacuation, therefore, is the best way to avoid this hazard.

\section{Lava flows}

Lava flows rarely threaten lives because they move slowly enough for people to get out of their way. However, lava flows crush, burn, and bury structures in their path and start forest fires. At volcanoes like Mount Shasta, lava flows seldom occur at the outset of an eruption; they usually follow a period of explosive activity. Lava flows threaten areas only in their path downslope, and the locations of these areas become evident when the lava appears and when its rate of flow is determined. It is generally not practical to attempt to divert or stop large lava flows.

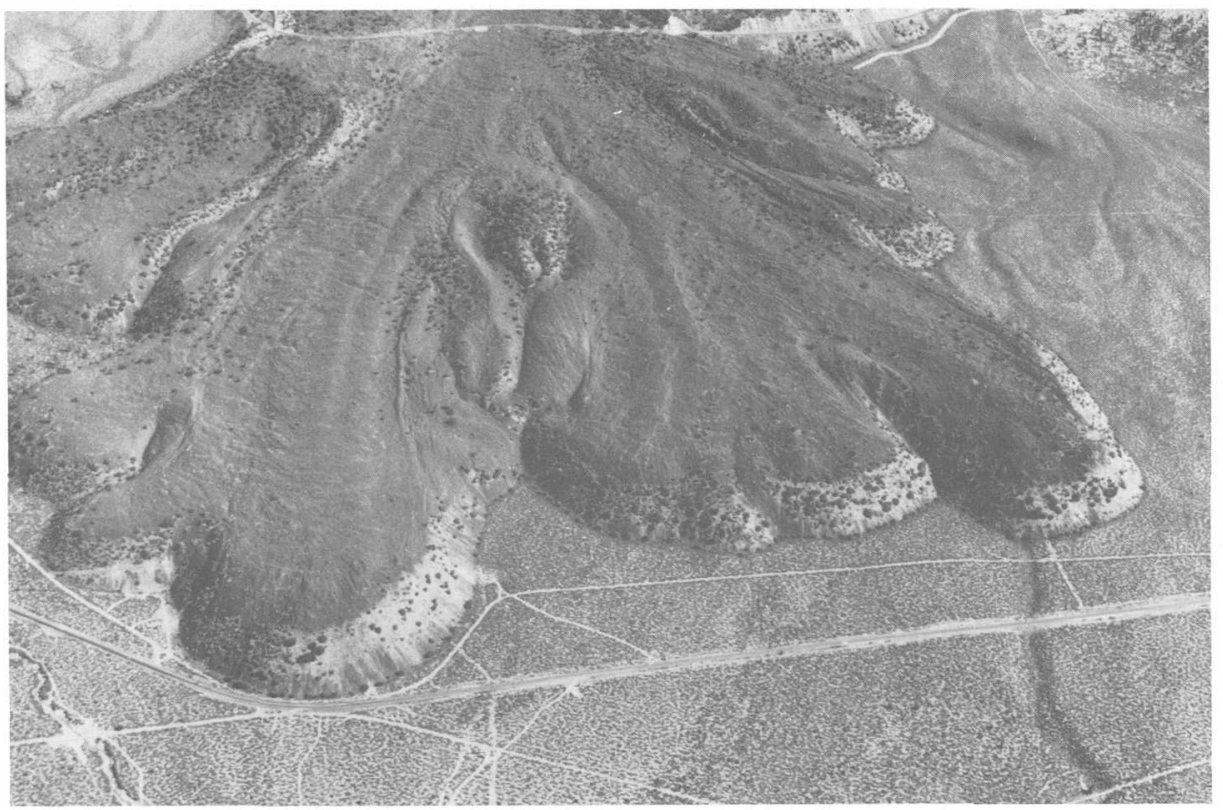

Front of a prehistoric lava flow at the north base of Mount Shasta. The broad line crossing the photograph near the bottom is U.S. Highway 97. The area shown in this aerial view is about 1 mile wide. 


\section{. Domes}

Some lavas are so stiff and pasty that they pile up over a vent as a volcanic dome. Such a dome has been forming in the crater of Mount St. Helens since 1980. Black Butte at the west base of Mount Shasta is a large volcanic dome that was formed between 9,000 and 10,000 years ago.

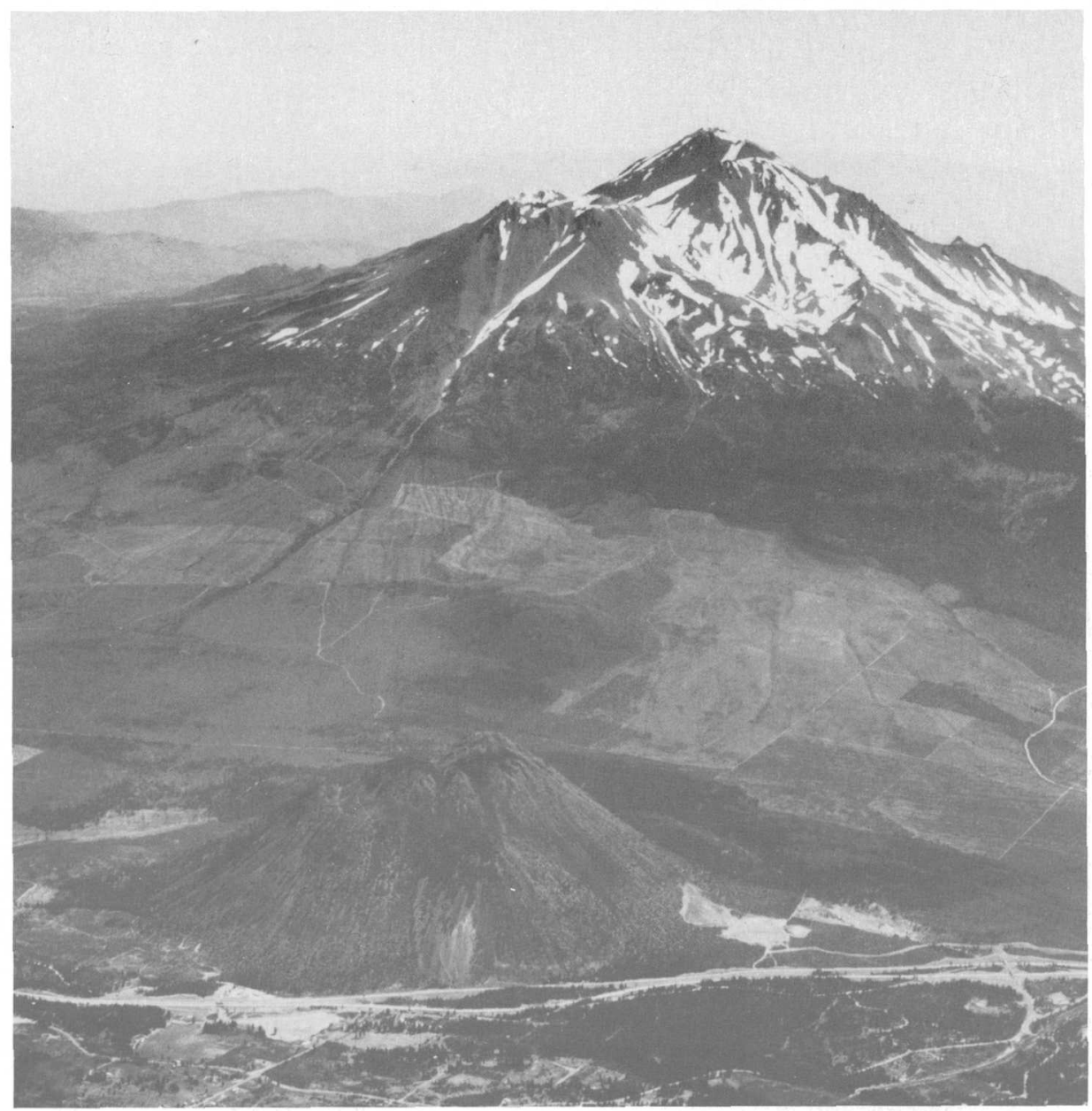

Black Butte, the conical hill in the foreground, is a volcanic dome. Interstate Highway 5 skirts the western base of the dome.

Domes themselves rarely endanger people directly, but dome growth can threaten lives in two ways. First, gas explosions within domes may hurl large rock fragments as much as 6 miles, although the risk to life and property decreases rapidly with distance from the site of the explosion. Second, the unstable sides of growing domes may break away and form pyroclastic flows that threaten areas directly downslope. During the formation of Black Butte, for example, avalanches of hot rock debris from the sides of the dome caused pyroclastic flows that spread about 2 miles to the north and west and 5 miles to the south. 


\section{Mudflows}

A mudflow is a mass of water-saturated rock debris that moves downslope as a fluid. During movement, a mudflow looks like a flowing mass of wet concrete; after it comes to rest and dries out, it looks like bouldery concrete although it is not cemented.

Mudflows can form when lava flows, pyroclastic flows, or hot lateral blasts melt snow on the side of a volcano. Such mudflows probably will carry hot rock debris. Mudflows also can form when rains soak masses of loose rock debris lying on steep slopes and when a body of water within a glacier suddenly escapes.

Mudflows tend to follow stream valleys, where they may travel tens of miles. Mudflows that have moved down channels on the steep upper slopes of Mount Shasta generally have spread out as they reached the gentler slopes near the base of the volcano. The speed of mudflows commonly is 10

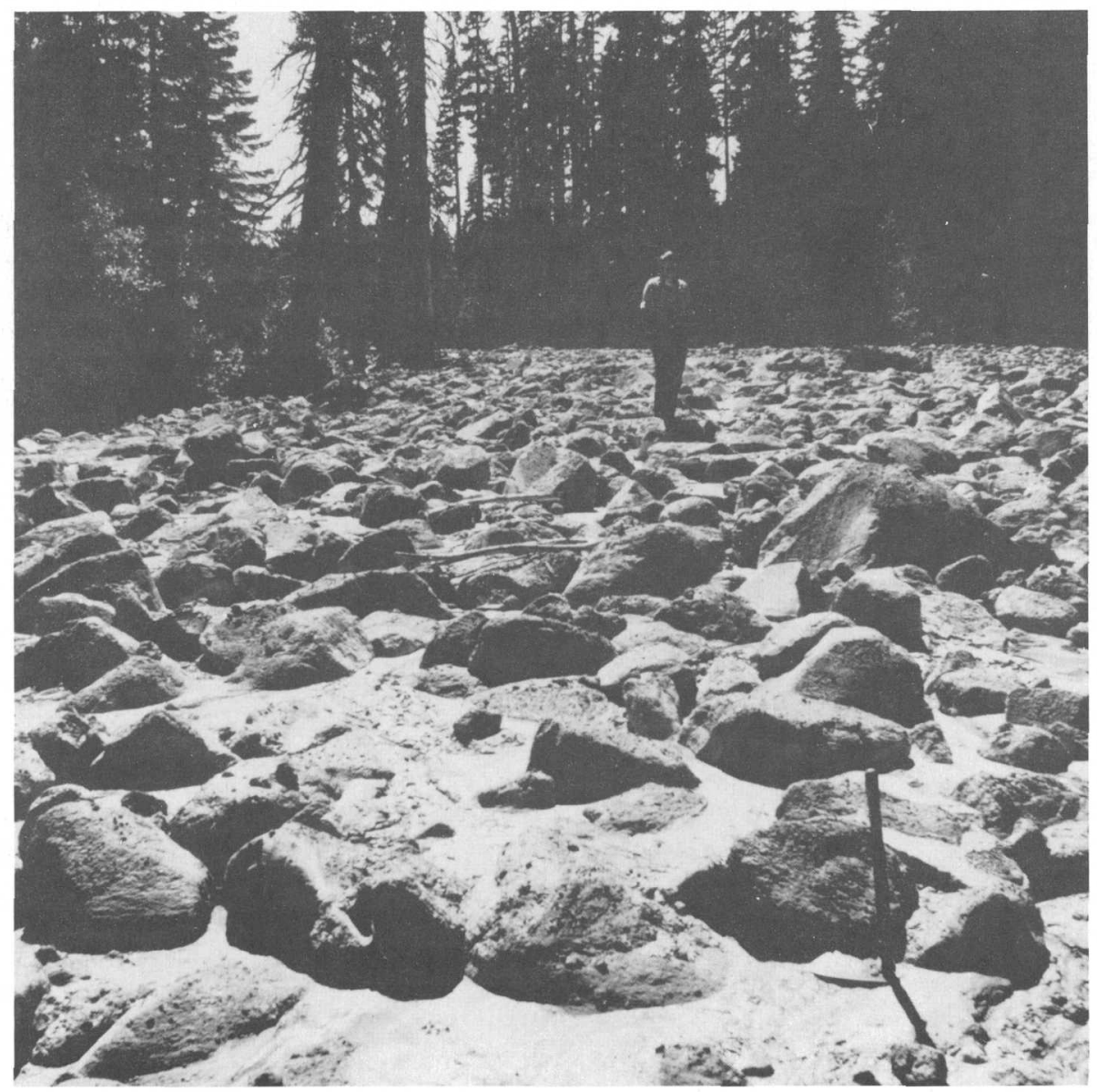

Deposit of a mudflow that moved more than 12 miles down Ash Creek on the east side of Mount Shasta during the summer of 1977 . The deposit is about 16 feet thick. 


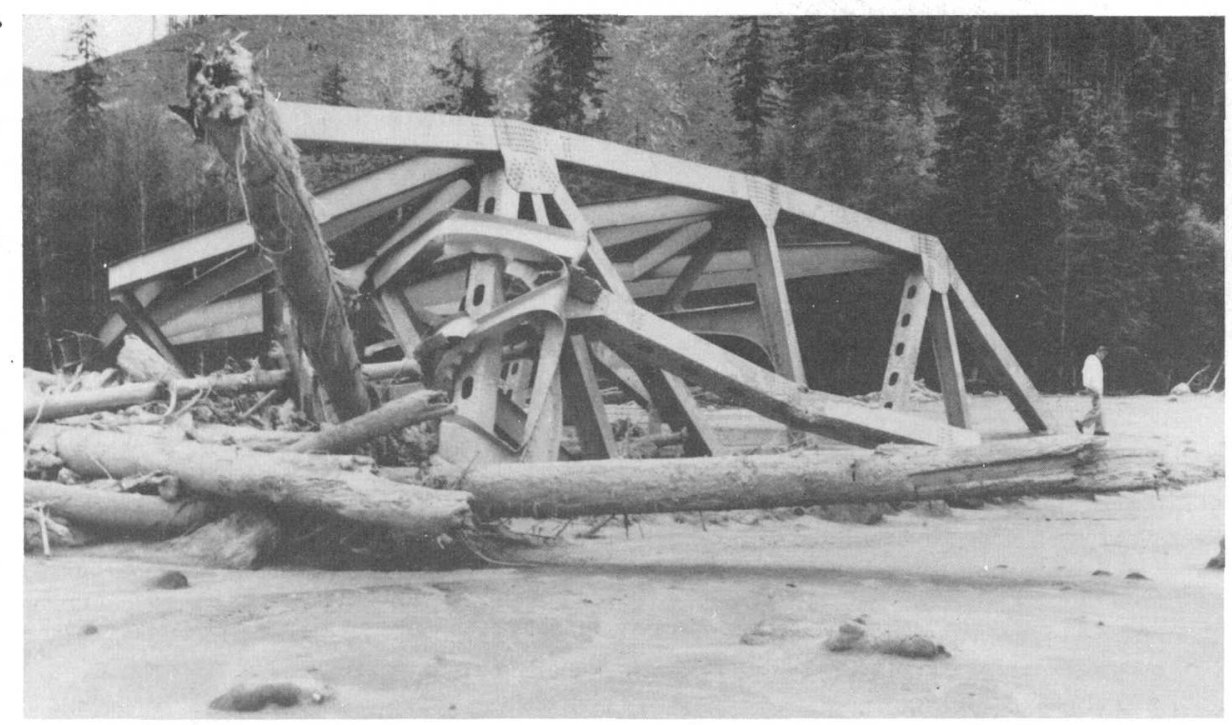

Steel highway bridge that was carried about one-fourth mile downstream by a mudflow from Mount St. Helens on May 18, 1980.

to $20 \mathrm{mph}$, but they can travel much faster on steep slopes.

Mudflows can sweep away or bury people, animals, and agriculture in their paths, and hot boulders carried in some mudflows can cause severe burns. Mudflows can smash, bury, or carry away buildings and other large and heavy structures such as bridges. Mudflow deposits only a few feet thick can kill crops and other vegetation.

Stream channels and adjacent flat or gently sloping areas at the base of the volcano are especially susceptible to being affected by mudflows. Dikes and other structures can trap or divert mudflows, but they may not be economically practical to build. People can generally avoid mudflows, however, by leaving threatened areas or by moving to high ground when mudflows seem likely.

\section{Landslides}

A large landslide of rock debris from the side of the volcano could be started by a volcanic explosion or by a severe earthquake and could move at high speed beyond the base of the volcano. A landslide triggered by an earthquake at Mount St. Helens on May 18, 1980, traveled about 14 miles beyond the volcano. That landslide was followed by a violent eruption. A much larger landslide moved down the north flank of Mount Shasta many thousands of years ago; part of its deposit forms the hundreds of small hills in Shasta Valley between Weed and Montague.

There is no known way to predict the location, size, or time of future catastrophic landslides at Mount Shasta, or even if any will occur. The likelihood of a landslide is greatest during a period of eruptive activity, 
especially if that activity is accompanied by earthquakes. By monitoring the slopes of the volcano, scientists may be able to detect ground changes that increase the probability of a landslide. In that event, downslope areas could be evacuated. Large landslides, however, have occurred at other volcanoes with little or no warning.

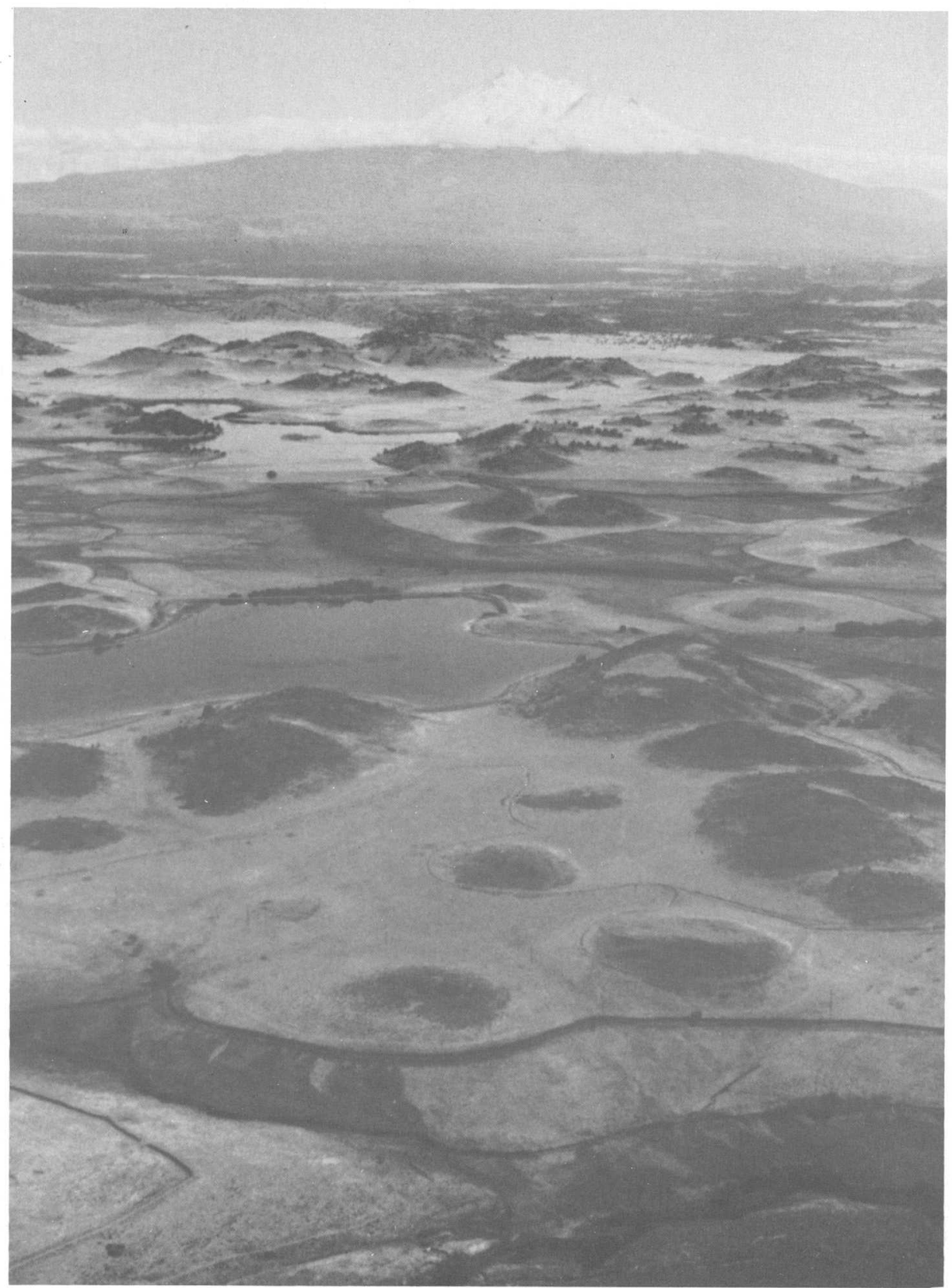

Small hills between Weed and Montague were formed thousands of years ago by a very large landslide of rock debris from Mount Shasta. 


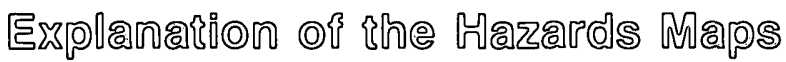

Four maps on the following pages show areas that could be endangered by eruptions that produce volcanic ash, pyroclastic flows and lateral blasts, lava flows, and mudflows. Some of these maps are divided into several hazard zones, the sites and shapes of which differ for each kind of hazard.

All eruptions of Mlount Shasta during the last 3,500 years have been located at the summit and have affected mostly the northern and eastern sides of the volcano. Most of the hazard maps are based on the assumption that the next eruption also will be at the summit of the volcano. If an eruption starts at a vent on the flank of the volcano, however, hazard zones must be modified accordingly. Areas that might be subject to large landslides can best be recognized after volcanic activity begins and, therefore, are not shown on the maps.

Although maps like these are designed primarily for long-range planning of land use around a volcano, they also can be used to plan ways in which communities can respond to the threat of an eruption. After eruptive activity begins, however, scientists will prepare hazards assessments and maps that reflect the kind and location of the eruption and that better identify possible danger areas.

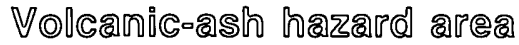

The thickness and extent of ash from a future explosive eruption would depend mostly on the volume of ash erupted and on the direction and strength of winds at that time. During the largest ash eruption at Mount Shasta in the last 10,000 years-about 9,600 years ago-the winds carried the ash generally eastward from the volcano. The thicknesses of this ash deposited at various distances from the volcano are used as a guide on the accompanying map to show thicknesses that could result from a future ash eruption of similar size. The thicknesses shown, however, have no special meaning with respect to possible danger to human life. People have survived ash falls 10 or more inches thick, apparently without ill effect, but the rate of accumulation and grain size also help to determine the health effects of ash. An ash layer a few inches thick almost certainly would halt all vehicle traffic, perhaps for as long as a week. A layer only a fraction of an inch thick could seriously disrupt electrical services, transportation systems, business activities, and community services. Thus, areas well beyond the 1 -inch circle on the accompanying map could be affected adversely by an ash fall.

The ash from any single eruption in the future probably will fall in a wedgeor oval-shaped area in a downwind direction. On an annual average basis, 67 percent of winds between alsitudes of about 10,000 and 52,000 feet in northern California blow toward directions between northeast and southeast, and about 90 percent blow toward some easterly direction between due north and due south. Thus, the probability is high that most ash from future eruptions will fall east of the volcano. Nevertheless, winds blow westward a small percent of the time, and a future ash eruption could occur at such a time. For 
this reason, each line of possible ash thickness is shown at the same distance in all directions from the volcano.

Large rock fragments thrown into the air by an explosion at the summit of Mount Shasta probably would not reach much farther than 6 miles, and thus such fragments would be restricted to the upper slopes of the volcano within the 15-inch circle shown on the ash-hazard map.

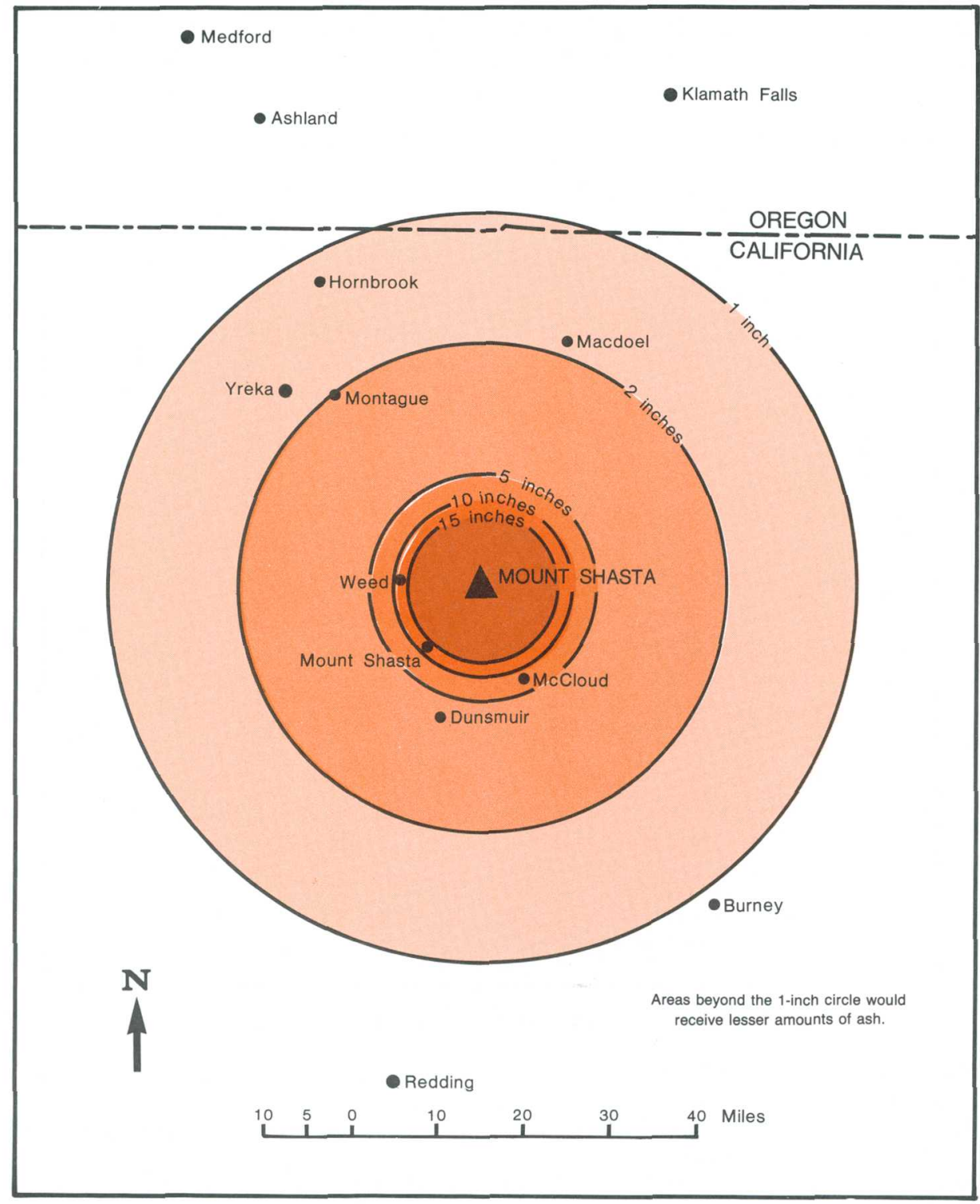

Volcanic-Ash Hazard Area Map

Thicknesses at various distances are based on the largest ash eruption of the last 10,000 years at Mount Shasta. Because of prevailing wind directions, ash most likely will fall somewhere east of a north-south line through the center of the volcano. 


\section{Pyroclastic flow and lateral blast hazard zones}

Pyroclastic flow hazard zones shown on the accompanying map include hazards from pyroclastic flows, ash hurricanes, and their accompanying clouds of ash. The boundaries of the zones are irregular because they are located at the base of hills or mountains. Most pyroclastic flows that originate at the summit of Mount Shasta probably would end somewhere within zone 1 ; thus, this is the zone of highest hazard during any eruption that would produce pyroclastic flows. The outer limit of zone 2 is placed at a distance equal to the longest single pyroclastic flow of the last 10,000 years at Mount Shasta. This zone is less likely to be affected by pyroclastic flows than zone

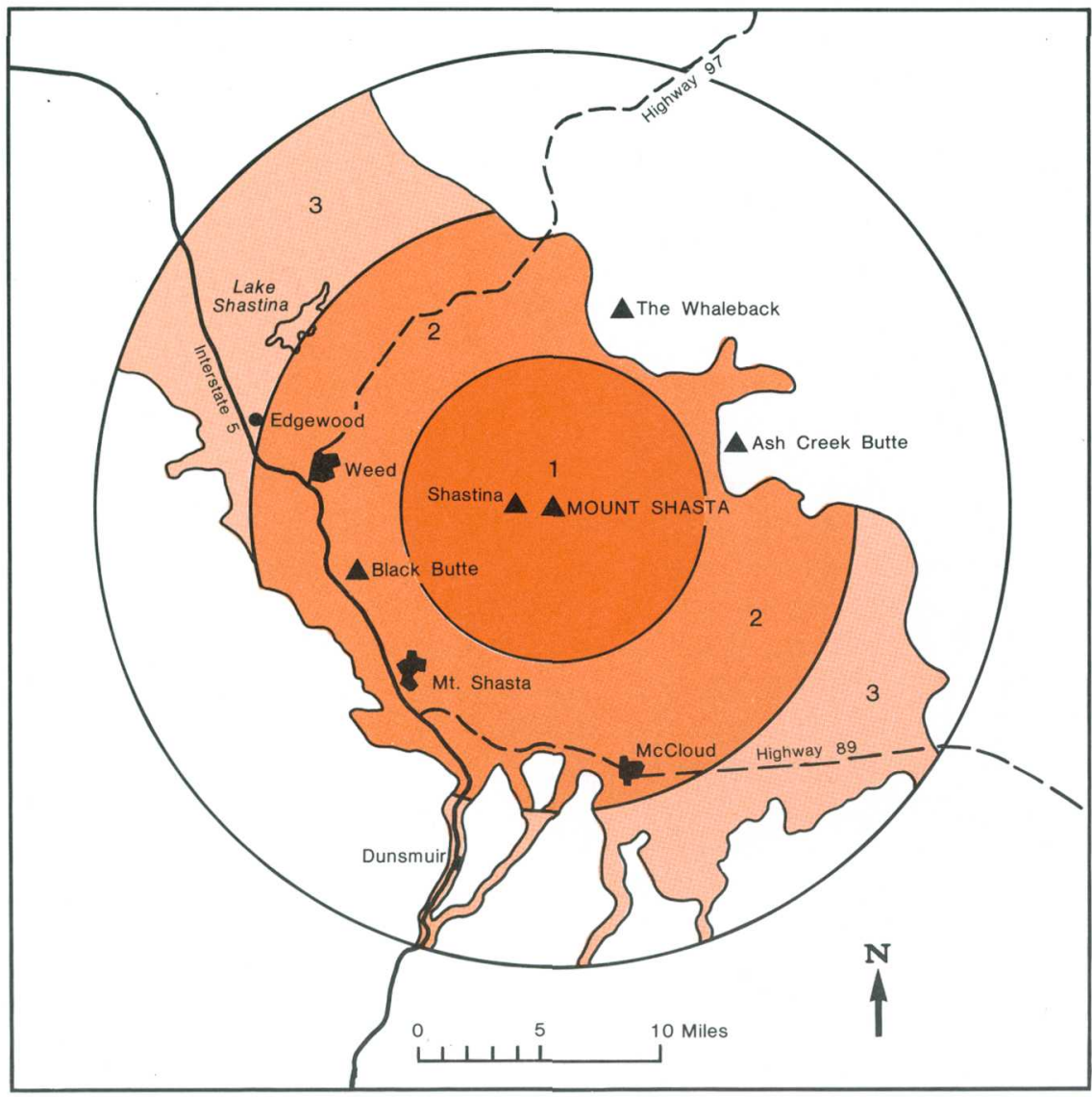

Pyroclastic Flow and Lateral Blast Hazard Zones Map

Zone 1-Areas likely to be affected most frequently by future pyroclastic flows, ash hurricanes, and associated ash clouds.

Zone 2-Areas likely to be affected less frequently by future pyroclastic flows, ash hurricanes, and associated ash clouds.

Zone 3-Areas likely to be affected mostly by ash clouds associated with pyroclastic flows in zones 1 and 2, but could also be affected by very large but infrequent pyroclastic flows.

A lateral blast could affect any area within the outermost circle, but the likelihood of an area being affected decreases with increasing distance from the volcano. The boundaries of zones 1, 2, and 3 are irregular because they are located at the base of hills or mountains. 
1 , and its outer part is less likely to be affected than its inner part. It is even less likely that pyroclastic flows will affect zone 3 , but this zone could be avoided as an extra safety measure during explosive eruptions because such flows could extend to the outer limit of the zone.

The outer limit of zone 3 also is the probable maximum outward extent of a lateral explosive blast like that of 1980 at Mount St. Helens. Although a lateral blast would affect only a portion of this circular zone, it is not possible now to anticipate the direction a lateral blast could take. This direction, however, might be predicted by scientists after an eruption began.

If scientists believe that an eruption is likely, responsible public officials might recommend or require temporary evacuation of zone 1 and possibly of zone 2. After an eruption began, areas of relative safety and danger might be anticipated from the kind of eruption and the location of the active vent.

\section{Lava-flow hazard zones}

The hazard zone map for lava flows shows two kinds of subdivisions. One is based on distance from the summit of the volcano, and the other is based on the areas of the volcano where lava flows are more or less likely. The upper slopes of the volcano are in zone 1; most future flows from summit eruptions probably would stay within this zone. Zone 2 could be affected by long lava flows originating within zone 1 as well as by flows erupted from vents within zone 2. Zone 3 could be affected by long lava flows erupted at vents within zone 2. New vents are possible but unlikely within zone 3.

The recent history of Mount Shasta suggests that most future lava flows will originate at the summit or on the northeastern flank of the volcano in sector A. Lava flows are less likely in sector B, the area on the south and west flanks of Mount Shasta.

By combining sectors and zones you will see that the overall lava flow hazard is highest in area $A 1$, and progressively decreases through areas $A 2$, $A 3, B 1, B 2$, and $B 3$. 


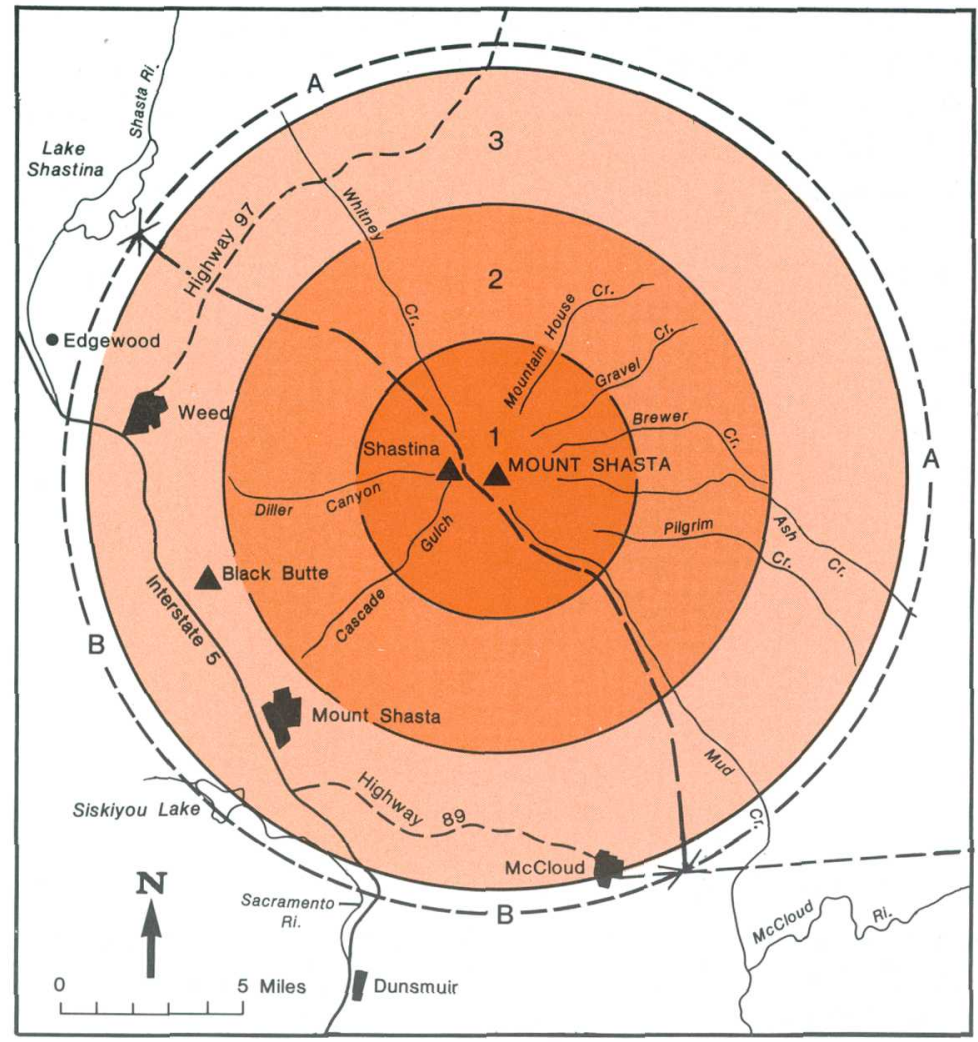

Lava Flow Hazard Zones Map

Circular numbered zones show possible hazard from lava flows with respect to distance from the top of the volcano.

Zone 1-areas likely to be affected most frequently.

Zone 2-areas likely to be affected by lava flows erupted at flank vents or that move into zone 2 from zone 1.

Zone 3-areas likely to be affected infrequently and then only by long lava flows that originate at vents in zones 1 and 2.

Lettered sectors show possible hazard from lava flows with respect to areas in which they are likely to occur. Lava flows are most likely in sector A, and less likely in sector B.

\section{Mudflow hazard zones}

Mudflow hazard zones A, B, and C are areas that could be threatened by future mudflows. Zone A includes the eastern part of the volcano that reaches from Whitney Creek on the north to Mud Creek on the south and that extends across flat areas beyond the base of the volcano. Zone A is the zone of greatest danger from future mudflows because it includes the parts of the volcano where future eruptions are most likely, and also areas downslope from these possible vents. In addition, mudflows not related to volcanic activity have affected some parts of this zone within the last few decades. Mudflow hazard zone B shows areas in which mudflows are possi- 
ble but less likely than in zone A. Zone B includes valleys on the west side of Mount Shasta and some areas between valleys on the east side of the volcano. Zone $C$ includes all other areas on the sides of Mount Shasta where future mudflows are possible, but where there have been none during the last 9,000 years.

If scientists believe that Mount Shasta is about to erupt, local officials might recommend or require evacuation of one or more zones until the eruption begins and the possibility of mudflows becomes apparent. Scientific assessment of mudflow danger would then be based on the nature and location of the eruption and the amount of snow on the volcano; the assessment might indicate that only part of a certain mudflow hazard zone is in danger.

The hazard from mudflows decreases rapidly with greater height above river channels; thus, high areas within the mudflow hazard zones are safer than are low areas. A mudflow hazard extends along the valley floors of the Shasta and McCloud Rivers far beyond the limits of the accompanying map.

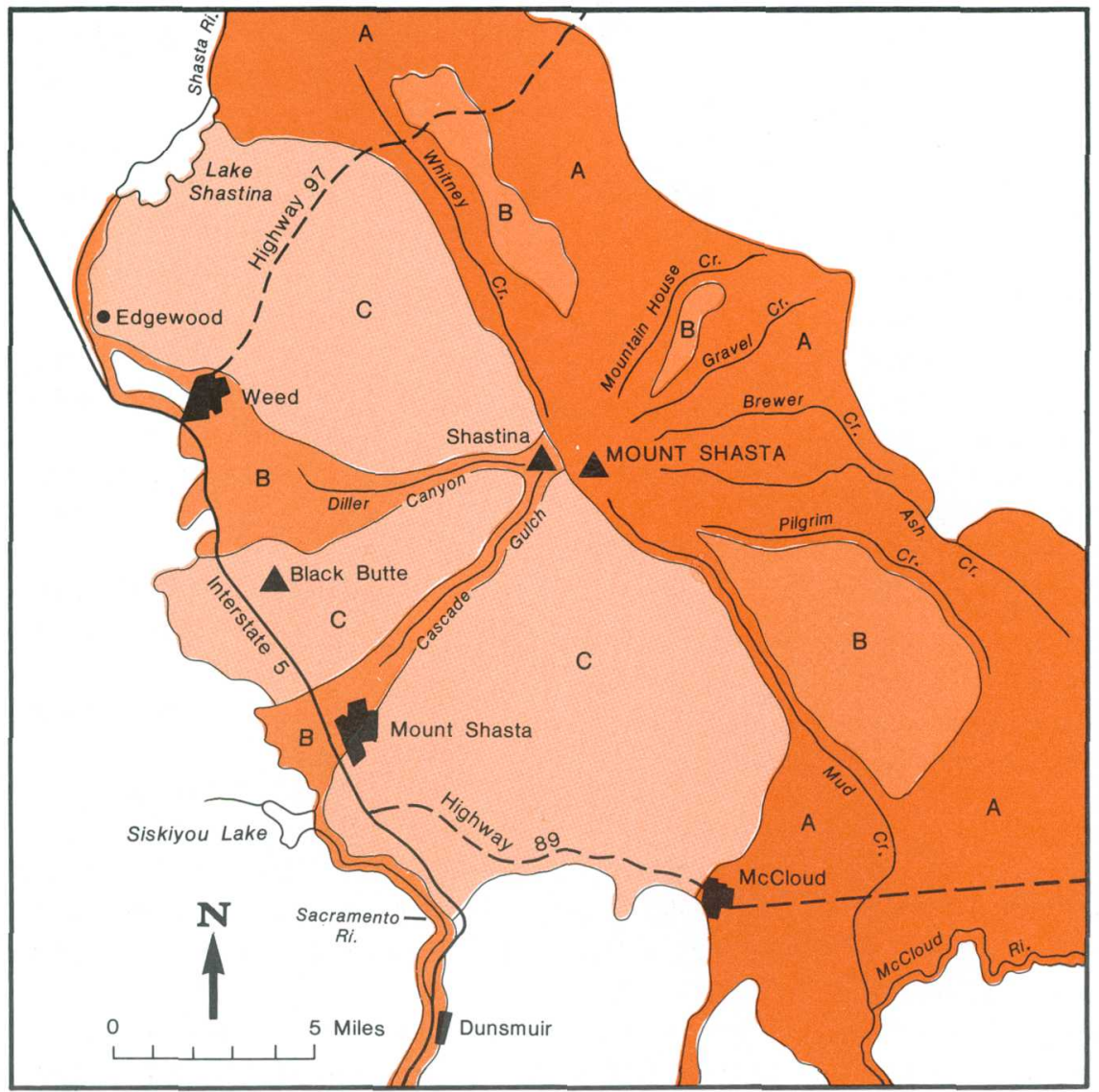

Mudflow Hazard Zones Map

Zones designated by letters show relative likelihood of being affected by future mudflows. Zone $\mathrm{A}$ is most likely and zone $\mathrm{C}$ is least likely to be affected. No mudflow hazard exists on high areas within or beyond the zones. Hazard decreases everywhere within the zones with greater height above stream channels and greater distance from Mount Shasta. 


\section{How to Prepare For and Cope With an Eruption}

Plan ahead. You can do many things to protect yourself, and thinking about them and planning for them could help you survive an eruption. Remember, an eruption could begin at any time of the day or night and during any kind of weather. Its effects could interrupt water supplies, clog sewers, block roads, cut electrical power and telephone service, and possibly require you to leave your home to protect yourself. Here are some suggestions:

-DON'T PANIC. Do not take some quick, impulsive action if an eruption begins, or if you are advised that an eruption is predicted or has started. By doing so, you may unnecessarily endanger your life.

- If an eruption begins, generally it is better for public officials to contact you than for you to attempt to contact them by telephone unless a hazardconfirmation telephone center has been established. In emergencies, public officials and their staffs are under great pressure. Incoming calls can tie up telephone lines, and attempting to answer dozens or hundreds of telephone calls could make the situation worse.

- The public will be advised if certain precautions are needed, such as staying indoors, not driving, or leaving certain areas. You also may be advised to store water, to have extra food on hand in case your area becomes temporarily isolated, to keep adequate fuel in vehicles in case evacuation becomes necessary, and to have a battery-operated radio for receiving emergency messages.

-Familiarize yourself with plans made by local officials for warning you and evacuating your area if that should become necessary.

- If an eruption begins, do not try to approach the eruption site because you could be killed by a sudden explosion. After consulting with scientists, public officials may designate safe viewing sites.

- The start of volcanic activity may require closing some areas and roads. Do not try to evade roadblocks and enter closed areas; you may risk your own life and, if you need to be rescued, the lives of others.

- If ash is being erupted, avoid areas downwind from the volcano because they will be most severely affected.

- A building offers good shelter from an ash fall. A building, however, offers little protection from a pyroclastic flow or ash hurricane; rock debris would break the windows and, if hot, could set fire to the structure. Escape would not be possible because the building would be surrounded by hot ash and rock debris. The best guarantee of safety is to leave dangerous areas before such events begin.

-Although mudflows can occur even when there is no volcanic activity, such activity greatly increases their likelihood. The danger from a mudflow increases as you approach a stream channel and decreases as you move away from a channel toward higher ground. Mudflows may move faster than you can walk or run. Before crossing a bridge, look upstream, and do not cross if a mudflow is approaching or moving beneath the bridge, because the bridge might be destroyed and leave you trapped. 
-Know what hazards are predicted in the general area where you live; if you are in an area that has a relatively high likelihood of being affected if an eruption occurs, think about what kinds of actions you and your family would take if volcanic activity was predicted or actually began.

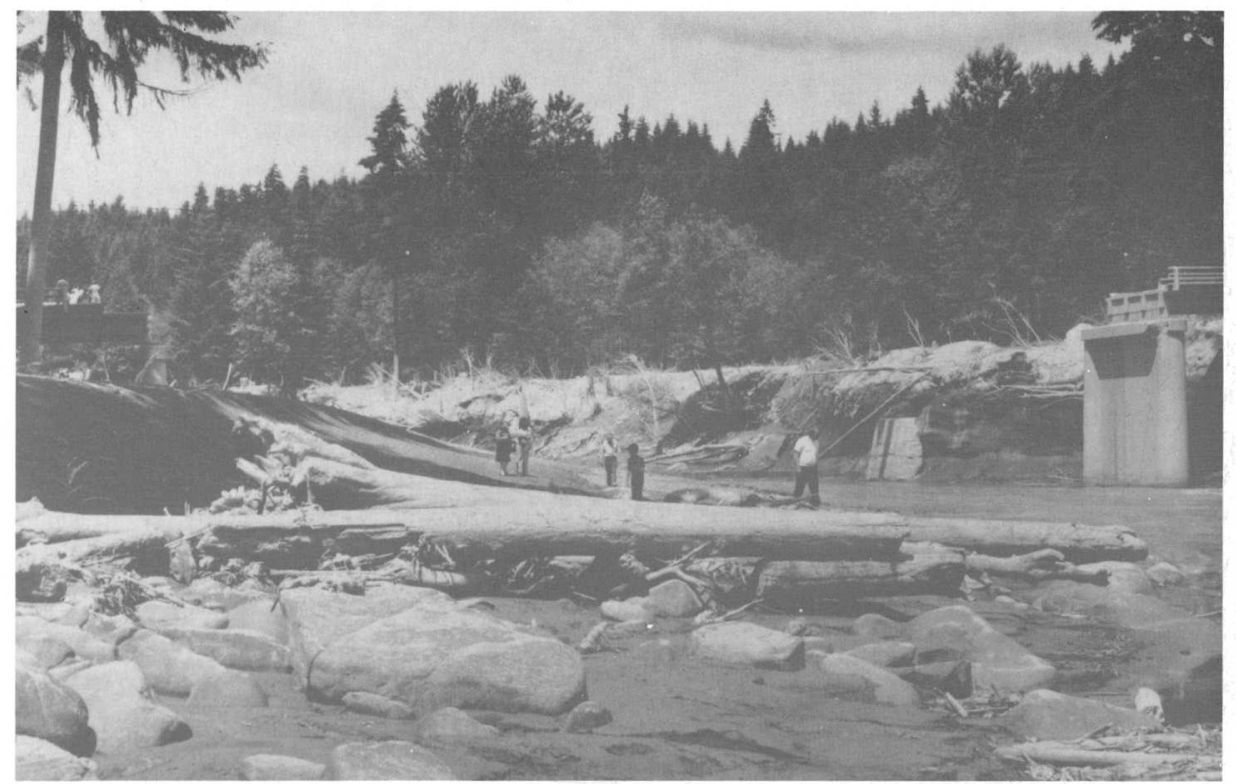

The highway bridge at this location was destroyed by a mudflow from Mount St. Helens on May 18, 1980.

\section{Forecasting the Next Eruption}

Scientists cannot yet accurately predict when long-dormant volcanoes like Mount Shasta will erupt again. Repeated earthquakes centered beneath a volcano generally are the first signal of an impending eruption; even so, such earthquakes may not be followed by an eruption. Other kinds of geologic events that often precede eruptions, such as the venting of gases and swelling of all or part of the volcano, also can be detected by scientists, and some such events might suggest that an eruption will occur soon. No single event, however, is a wholly reliable guide for forecasting the exact time, place, and scale of an impending eruption. Furthermore, scientists are uncertain how a long-dormant volcano will behave when it does become active, and some eruptions can begin so quickly that people can do little to protect themselves. In view of this uncertainty, people near the volcano may be asked by public officials to take protective actions that might turn out to be unnecessary. 


\section{Responsibilities of Scientists and Local, State, and Federal Officials}

If earthquakes or other geologic events at Mount Shasta indicate the possibility of an eruption, the U.S. Geological Survey, the California Division of Mines and Geology, and university scientists will begin various kinds of monitoring to assess the likelihood of an eruption. After an eruption begins, scientists will be better able to anticipate what kinds of volcanic activity are possible and what specific areas could be affected. Scientists will then promptly advise public officials and the public as to potential hazards. Scientists will not decide what protective actions should be undertaken; these decisions will be made by public officials who must consider social and economic factors as well as scientific information.

Local officials are responsible for providing for public health, safety, and welfare. They will weigh the need to evacuate threatened areas, to close highways and airports, and to take other public-safety actions. Through its Office of Emergency Services, the State of California also plans emergency responses to potential disasters. If an eruption occurs or seems likely, the Governor of California may declare a state of emergency and assume responsibility for ordering defensive actions over a broad area, and the Governor may ask certain State agencies to assist local governments. If the effects of an eruption are more than State agencies and local governments can handle, the President of the United States may issue a National Disaster Declaration. Such a declaration would enable the Federal Emergency Management Administration (FEMA) to coordinate Federal assistance programs, which include search and rescue operations, setting up field hospitals, and arranging for loans and other financial assistance to victims.

\section{Additional Information}

This pamphlet is based mostly on information in U.S. Geological Survey Bulletin 1503, entitled "Potential hazards from future eruptions in the vicinity of Mount Shasta volcano, northern California," by C. Dan Miller, which provides additional details of hazards at the volcano as well as hazard maps like those in this pamphlet. The bulletin is available for reference at libraries in the Mount Shasta area. It can also be obtained from: Book and Open-File Reports Section, U.S. Geological Survey, Federal Center, Box 25425, Denver, CO 80225 . Contact the Section for price and ordering information. 
As the Nation's principal conservation agency, the Department of the Interior has responsibility for most of our nationally owned public lands and natural resources. This includes fostering the wisest use of our land and water resources, protecting our fish and wildlife, preserving the environmental and cultural values of our national parks and historical places, and providing for the enjoyment of life through outdoor recreation. The Department assesses our energy and mineral resources and works to assure that their development is in the best interests of all our people. The Department also has a major responsibility for American Indian reservation communities and for people who live in Island Territories under U.S. administration. 